\title{
Simplified RESTRUCTURING PROCEEDINGS \\ in Poland as an EXAmple of ANTi - CRISIS \\ REGULATION DUE TO THE COVID-19 PANDEMIC
}

\author{
Rafal Adamus
}

University of Opole, Institute of Legal Sciences, Poland

radamus@uni.opole.pl

ADAMUS, Rafał. Simplified restructuring proceedings in Poland as an example of anti - crisis regulation due to the COVID-19 pandemic. International and Comparative Law Review, 2020, vol. 20, no. 1, pp. 293-303. DOI: 10.2478/ iclr-2020-0014

\begin{abstract}
Summary: The study discusses new legislative anti - crisis solutions adopted in Poland in connection with the COVID - 19 pandemic. The Polish legislator decided to introduce the so-called simplified restructuring procedure. This happened in the face of the expectations of both the jurisprudence of law and practice. On the one hand, the simplified restructuring procedure (the fifth independent type of restructuring procedure for an entrepreneur in Poland) allows for a quick, cheap and simplified conclusion of an arrangement with creditors outside the court, then approved by the court. On the other hand, the opening of such proceedings gives the debtor protection against enforcement at the creditor's request and against bankruptcy at the creditor's request. This procedure can be a testing ground for the concept of informalisation and acceleration of restructuring procedures.
\end{abstract}

Keywords: COVID-19, entrepreneur, insolvency, bankruptcy, restructuring, simplfied restructuring proceedeings

\section{Introduction. The purpose of the study}

The purpose of this study is to present the assumptions relating to the socalled simplified restructuring procedure introduced by the Polish legislator in response to the COVID - 19 pandemic. In Poland, modern restructuring law ${ }^{1}$ is in force, providing for as many as four types of restructuring proceedings ${ }^{2}$. The Polish legislator has not introduced yet any direct changes adjusting the domestic law to the so-called the Restructuring Directive ${ }^{3}$. However it occurred nec-

1 Act on 15th May 2015 r. Prawo restrukturyzacyjne (Restructuring Law Act), Of. Jour. 2015, no 978 as amended

2 ADAMUS Rafał, Bankruptcy and Restructuring Law in Poland, Societas et Iurisprudentia 2019, vol. VII, issue 2, Trnava, Slovakia, p. 19-49, ADAMUS Rafał, Grounds for opening restructuring proceedings in Poland, Gaps in Russian Legislation, Moscow 2018, no 7, p. 162-166.

3 Directive (EU) 2019/1023 of the European Parliament and of the Council of 20 June 2019 on preventive restructuring frameworks, on discharge of debt and disqualifications, and 
essary to design an additional, fifth procedure facilitating the conclusion of an agreement. Changes in the law provoked a discussion whether the insolvency law should not only serve to maximize the satisfaction of creditors, restructure the debtor but also serve for the protection of economic interests of the state. The dissemination of insolvency procedures raises the question of the need to change the traditional, conservative approach to restructuring ${ }^{4}$.

\section{General remarks}

The global epidemic of 2020, caused by the SARS-CoV-2 virus, in many countries led to the phenomenon of insolvency of entrepreneurs or at least to the threat of their insolvency under provisions of a proper lex concursus ${ }^{5}$. As a result of administrative orders of the authorities related to the epidemic (closing or restriction of economic activity, decreasing activities of some public institutions, cancellation of cultural and sports events, restriction of movement, closing of borders, etc.), entrepreneurs unexpectly lost their sources of income. Ordinairy legal solutions directly or indirectly related to insolvency turned out to be inadequate to deal with the common crisis. Many countries introduced in their legislation special and extraordinairy solutions to stop or decrease the upcoming crisis ${ }^{6}$. Anti-crisis COVID-19 legislation is situated on pretty diffrent levels.

First, there should be mentioned a level of state (public) aid regulation (in the national and supranational dimension in EU member states). Nowadays the idea of "the night-watchman state" is no longer valid. "The invisible hand of the market” should be remarkably supported by „the heavy hand of government“. The economic crisis may be reduced as a result of state intervention (state aid), appropriate monetary policy of central banks, etc. Relations between the state and entrepreneurs are vertical. Both the EU and EU member states intend to limit the negative effects of the epidemic caused by the SARS-CoV-2 virus on the economy by granting financial aid. Granting state aid for the purpose of saving or restructuring entrepreneurs is generally based on the following assumptions. The guiding principle stipulates that support may be provided to entrepreneurs if it prevents and leads to the reduction of social difficulties or overcoming market failures, where, without granting it, this objective would not be achieved, or

on measures to increase the efficiency of procedures concerning restructuring, insolvency and discharge of debt, and amending Directive (EU) 2017/1132 (Directive on restructuring and insolvency).

4 ADAMUS Rafat, The need for change in the approach to insolvency of sports clubs in the regulation of the European football federation, Balkan Social Science Review 2020, vol. 15, p. 197-219

5 BEIRNE John, RENZHI Nuobu, SUGANDI Eric, and VOLZ Ulrich, Financial Market and Capital Flow Dynamics During the COVID-19 Pandemic https://papers.ssrn.com/sol3/ papers.cfm?abstract_id $=3656848$

6 GUERRA - MARTINEZ Aurelio, Insolvency Law in Times of COVID-19, https://papers. ssrn.com/sol3/papers.cfm?abstract_id=3562685 
would be achieved to a lesser extent. State aid may be granted up to the amount of funds allocated for this purpose.

The aim of the law is, inter alia, appropriate shaping of social relations. In the event of an entrepreneur's insolvency, there are basically two standard pathways for satisfying creditors ${ }^{7}$. Entrepreneur's property may be sold out - by a trustee - to another person (or persons). In such a case creditors will be satisfied with the sale price. However an entrepreneur may conclude an arrangement with creditors regarding new terms of repayment of liabilities and continue his commercial activity. Second, it should be stressed that the legal regulations concerning the threat of insolvency and insolvency of entrepreneurs are generally not designed to "handle“ the phenomenon of common insolvency during limitations in the work of bankruptcy and restructuring courts (other insolvency authorities), due to epidemic risks. Relations between insolvent debtor and his creditors are horizontal. In other words, ordinary legal solutions occurred being ineffective in extraordinairy situations. A further problem is related to the long time-consuming nature of traditional insolvency procedures (bureaucratic obstacles). Meanwhile, for a losing trader willing to conclude an arrangement with his creditors, time is the essence. This can be compared to the importance of intensive resuscitation of a person suffering from a heart attack. Too slow medical procedure is pointless. The other necessity for crisis times is freezing the duty to file for bankruptcy (involving forced liquidation of the bankruptcy estate which means the end of the activity of bankrupt's entreprise). The bankruptcy of a single entrepreneur, which is an element of economic relations, has a domino effect. The disruption of the supply and acceptance chain has a significant impact on the market environment (contractors, cooperatives) of the failing entrepreneur. On the other hand, the phenomenon of common bankruptcy of entire groups of entrepreneurs is of extraordinary macroeconomic importance. It can become dangerous on a national or regional scale, and sometimes even on a global scale. Common bankruptcies are not only about the destruction of economic structures. Their consequence is also a reduction in tax revenues to the state budget, a massive increase in unemployment, and impoverishment of the society. The shrinking economy offers fewer jobs. It should also be imposed on the progressive delaboration and the objective decrease in the demand for human labor resulting from technological progress. Up till now the COVID - 19 regulation in the field of insolvency law went in two directions. In such a case the obligation to file for bankruptcy should be limited. Moreover, the conclu-

7 LEWTIN Adam, Business Bankruptcy: Financial Restructuring and Modern Commercial Markets, Wolters Kluwer 2019, passim, ALTMAN Edward, HOTCHKISS Edith, WANG Wey, Corporate Financial Distress, Restructuring, and Bankruptcy: Analyze Leveraged Finance, Distressed Debt, and Bankruptcy, Wiley Finance, 4th Edition, passim,

UNICITRAL Legislative Guide on Insolvency. Part One. Designing the Key Objectives and Structure of an Effective and Efficient Insolvency Law, New York 2005, p. 9-37 
sion of the arrangement should be facilitated by accelerating and simplifying procedures $^{8}$.

Third, a number of provisional solutions have been introduced to regulate tax and social insurance obligations, employee relations, and private law relations ${ }^{9}$.

\section{Freezing debtor's duty to file for bankruptcy}

According to Polish law, it is the debtor's duty and responsibility to file a bankruptcy petition in case of his insolvency. However it is the privilege of the debtor to submit an application for restructuring. The opening of restructuring proceedings excludes declaration of bankruptcy. Thus the freezing of the obligation to submit a bankruptcy petition can be read as an invitation to restructuring.

In connection with the COVID-19 pandemic, on March 13, 2020, the Minister of Health issued an ordinance on the declaration of an epidemic threat in the territory of the Republic of Poland, and then on March 20, 2020 on a declaration of an epidemic in the territory of the Republic of Poland. Total or partial ban on conducting some kinds of commercial activity have been inroduced. A special provision provided for a regulation under which the deadline for the debtor to file for bankruptcy (Article 21 section $1 \mathrm{PrUpad}^{10}$ ) in the period of epidemic threat or the epidemic „does not start, and the started is interrupted“. After this period, „the term runs anew.“ At the same time, a rebuttable presumption (iuris tantum) has been introduced that if the state of insolvency arose during the epidemic threat or epidemic announced due to COVID-19, it is presumed that it occurred due to COVID-19. In other words, the legislator allowed the debtor not to file for bankruptcy despite the formal fulfillment of the grounds for insolvency. However, the debtor still retains the right to file for bankruptcy. Can a creditor file for bankruptcy? Through the bankruptcy procedure, there may be a hostile takeover of the entrepreneur's property.

The legislator did not freeze the creditor's right to file a petition for bankruptcy of the debtor during the period of epidemic threat or epidemic. At the same time, the Act excludes the possibility of suport (public aid) for entrepreneurs against whom restructuring proceedings have been opened. Thus, an entrepreneur against whom the creditor would file for bankruptcy - if he wants to benefit from public aid - in practice, he cannot defend himself against a creditor's bankruptcy petition with a counter-petition to open restructuring proceedings. It should be remembered that in the event of a merger of the bankruptcy petition and the opening of restructuring proceedings, the court first decides on the restructuring. The insolvency court should, however, take into account the

8 ADAMUS Rafał, The need for a special restructuring procedure for insolvent entrepreneurs due to SARS-CoV-2, Sociopolitical Sciences, Moscow no 2/2020, p. 128-131.

9 ADAMUS Rafał, Następcza niemożność świadczenia wynajmującego z terminowej umowy najmu, Folia Iuridica Universitatis Wratislaviensis 2019, vol. 8 (2), p. 190-204.

10 „PrUpad” - Act on 23th February 2003 Bankruptcy Law (Prawo upadłościowe). 
asymmetry caused by the regulation of the Act. Therefore, if, despite the fulfillment of the grounds for insolvency, as a result of the COVID - 19 epidemic, the legislator tolerates such a state of affairs by excluding the debtor's obligation to file for bankruptcy. This circumstance is also important in the case of a bankruptcy petition by the creditor. The court may dismiss the creditor's application with reference to the argument that in an epidemic emergency or on the state of the epidemic, the legislator does not absolutely order the elimination of insolvent entities from the market. Insolvent entrepreneurs are allowed to trade. This is a special situation and therefore requires a responsible approach. It is also possible that the insolvency court will not consider the creditor's application for bankruptcy of the debtor until the epidemic ceases, or even better, until the lapse of 30 days from the end of the epidemic. Any exceeding of the instruction deadline for considering the application seems justified. Moreover, the exclusion of the debtor's obligation to file a bankruptcy petition during an epidemic has a general social dimension. Too many bankruptcies could hinder the recovery of the entire economy. The court examining the creditor's application should take into account the fact that the epidemic resulted in structural insolvency. Hence, lightly considering creditors' insolvency applications could have a negative macroeconomic effect. The commercial court should also examine whether the creditor's bankruptcy petition was not filed in bad faith (mala fides). The position of the debtor himself will be important in each individual case. Particular caution should be recommended in the case of the creditor's application for bankruptcy of the debtor together with the application for pre-pack liquidation. This procedure could lead to a hostile seizure of the debtor's assets using the difficulties caused by the COVID 19 epidemic.

The mere freezing of the obligation to file for bankruptcy was not effective enough to counter the effects of the pandemic crisis in the area of insolvency law. In the bill of the provisions on simplified restructuring proceedings, the legislator raised the following: "The draft is aimed at enabling the debtor to enter into negotiations with creditors without the need to formally open the proceedings by the court, but with the simultaneous protection against enforcement conducted by creditors acting individually. It should be remembered that the exclusion of the obligation to file for bankruptcy referred to in the above-mentioned Article 15zzra of the Act on special solutions related to preventing and combating COVID-19, does not protect the debtor against the enforcement of claims by his creditors, which in practice may lead to the need to file for bankruptcy despite the real chances of continuing operations after carrying out remedial actions, in particular all by concluding an arrangement with the majority of creditors "11.

11 Print no. 382 of the Sejm (Lower Chamber of the Polish Parliament) of the 9th Term. 


\section{The essence of simplified restructuring}

\section{a) General remarks}

Simplified restructuring proceedings are of key importance. They were conceived as an ephemeral construction. The declaration on its opening may be submitted until July 31, 2021. The debtor has the right to choose the restructuring mode between simplified restructuring and general restructuring.

Simplified restructuring is based on the procedure for approval of the arrangement. The procedure for approval of an arrangement regulated in Restructuring Law Act (hereafter „PrRestr”) is the most informal and the simplest restructuring proceedings in Poland. The restructuring proceedings are for entrepreneurs who are insolvent or under the threat of insolvency. The basic proceedings for approval of the arrangement allow the conclusion of an arrangement as a result of the debtor's independent collection of creditors' votes without the participation of the court, and may be conducted if the sum disputed claims entitling to vote on the arrangement does not exceed $15 \%$ of the sum of claims entitling to vote on the arrangement (however in the simplified proceedings the sum of disputed claims is of no importance). Debtor's activities aimed at restructuring the debtor are largely conducted outside the court. The debtor independently selects the arrangement supervisor („nadzorca układu”), independently indicates the date (within the limits stipulated by the Act) which is the demarcation line between the liabilities subject to restructuring and liabilities not of such nature. The arrangement supervisor draws up a restructuring plan and a list of receivables. The debtor is the author of the arrangement proposals. The debtor may divide the creditors into categories of interest. Only the application for approval of the successfully concluded arrangement initiates the court proceedings. The effects of the opening of proceedings, in the basic model, arise on the arrangement date referred to in Article 211 (Article 189 section 2 PrRestr). In the basic model, there is no statutory moratorium on repayment of liabilities. Nevertheless, in the case of the simplified procedure, the legislator decided to introduce such a moratorium. In the basic model of the procedure for approval of the arrangement, protection against enforcement - referred to in Article 259, 260 PrRestr - the debtor obtains very late on the day of issuing the court ruling approving the successfully concluded arrangement (Article 224 section 2 PrRestr). Until then, creditors may enforce the debtor. In the case of simplified proceedings, the legislator decided to cover the debtor with anti-enforcement defense from the very begining - the moment of announcing the opening of the proceedings. The regulations - in the basic model - do not limit creditors in making a set - off, even if the creditor has obtained the claim by transfer (cessio). In the case of the simplified procedure, the legislator decided to introduce restrictions for creditors on the possibility of set-off. 
The simplified restructuring procedure uses the structure permitted only under the partial arrangement ${ }^{12}$. Under a partial arrangement it is possible what is equally important - to compulsorily include creditors secured on debtor's assets (Article 181 PrRestr).

\section{b) Independence of regulations}

Simplified restructuring proceedings is regulated in the separate anti-crisis $\mathrm{Act}^{13}$. The Act does not constitute a complex regulation of simplified proceedings. On the contary the Act refers to the general principles of conducting restructuring proceedings, contained in the Restructuring Law $\mathrm{Act}^{14}$.

\section{c) Opening the simplified procedure. Independence of the debtor's decision.}

Opening the proceedings is done by publishing a debtor's announcement in „Monitor Sądowy i Gospodarczy” (Court and Commercial Official Journal). The decision to publish such an announcement is solely the responsibility of the entrepreneur who has entered into a purely private contract with a licensed restructuring advisor (court supervisor). This means that the opening of the proceedings does not depend on the court's decision, although in the period after the opening of the proceedings it is possible to exclude some of the crucial effects of the opening of the proceedings by the court, in the event of the debtor acting to the detriment of creditors ${ }^{15}$. The legislator ensured the speed of opening the procedure. The certainity of the opening of the procedure was ensured as well. The debtor's declaration that the simplified proceedings have been opened is not subject to any preliminary (ex ante) control by the insolvency court or other public authority.

\section{d) Effects of the opening of the simplified proceedings - enforcement immunity.}

The opening of the simplified proceedings is to cause some of the effects that are currently envisaged in accelerated arrangement, arrangement or sanation proceedings, and are not possible at the stage before submitting an application for approval of an arrangement. The key solution, which is currently not possible in the case of basis proceedings for approval of an arrangement under the Restructuring Law Act, is the suspension of the enforcement of receivables

12 ADAMUS Rafał, Partial arrangement in the Polish Reorganization Law, Gaps in Russian Legislation, Moscow 2018, no 6, p. 305-308

13 Act on 19th June 2020 o dopłatach do oprocentowania kredytów bankowych udzielanych przedsiębiorcom dotkniętym skutkami COVID-19 oraz o uproszczonym postępowaniu o zatwierdzenie układu w związku z wystąpieniem COVID-19 (on subsidies to the interest rate of bank loans granted to entrepreneurs affected by the effects of COVID-19 and on simplified proceedings for approval of an arrangement in connection with the occurrence of COVID-19)

14 Print no. 382 of the Sejm (Lower Chamber of the Polish Parliament) of the 9th Term.

15 Print no. 382 of the Sejm (Lower Chamber of the Polish Parliament) of the 9th Term. 
covered by the arrangement by virtue of law, as well as receivables secured on debtor's assets and receivables secured by transfer of ownership for security ${ }^{16}$.

\section{e) Receivables secured on debtor's assets}

If the debtor provides for the arrangement of the claims secured on debtor's assets at and secured by transfer of ownership as security, he must demonstrate in the arrangement proposals that the arrangement provides for either full satisfaction of these claims or their satisfaction to a degree not lower than that which can be expected in in the case of vindication of receivables together with incidental receivables from the subject of collateral (Article 181 PrRestr applicable under a partial arrangement). This circumstance will be examined by the restructuring court at the arrangement approval stage ${ }^{17}$.

\section{f) Restriction of terminating certain contracts}

During the course of the simplified proceedings it will not be possible to terminate the lease or tenancy agreements and to meet the benefits resulting from the liabilities which are legally covered by the arrangement, on the terms currently in force in the accelerated restructuring proceedings (Articles 256 and 252 of the PrRestr). Also, the deductions will be allowed only under the terms of the accelerated arrangement procedure ${ }^{18}$.

\section{g) Optional meeting of creditors.}

It is introduced a possibility to convene a meeting of creditors by the arrangement supervisor in order to the gathering of votes without covening a meeting, in the manner provided for in the arrangement approval proceedings. Importantly, the meeting of creditors may be conducted with the use of electronic means of communication, which is already provided for under the Restructuring Law Act (Article $110 \mathrm{sec} .6$ PrRestr) ${ }^{19}$.

\section{h) Set aside of the effects of opening the simplified procedure}

In order to prevent possible abuses of the law by dishonest debtors and if it is considered pointless to maintain the effects of the opening of proceedings, it is foreseen that the creditor, the supervisor of the arrangement and the debtor himself may request that the effects of the opening of the proceedings be waived. The court ruling on waiving the effects of the announcement will be published ${ }^{20}$.

16 Print no. 382 of the Sejm (Lower Chamber of the Polish Parliament) of the 9th Term.

17 Print no. 382 of the Sejm (Lower Chamber of the Polish Parliament) of the 9th Term

18 Print no. 382 of the Sejm (Lower Chamber of the Polish Parliament) of the 9th Term

19 Print no. 382 of the Sejm (Lower Chamber of the Polish Parliament) of the 9th Term

20 Print no. 382 of the Sejm (Lower Chamber of the Polish Parliament) of the 9th Term 


\section{i) Limited duration of the simplified proceedings}

Granting the enforcement immunity the duration of negotiations aimed at concluding an arrangement is limited to 4 months. Failure to submit the application to the restructuring court for approval of the arrangement within this period results in the discontinuation of the proceedings by virtue of law. In this case, the court ruling on the discontinuation is of a declaratory nature and is made at the request of a person having a legal interest in this, including, in particular, the creditor or the debtor. If an application for approval of the arrangement is submitted to the court before the expiry of 4 months from the date of the announcement, the effects of the opening of the proceedings will last until the proceedings are legally terminated or discontinued. ${ }^{21}$

Bearing in mind that in the proceedings for approval of the arrangement, the debtor is obliged to conclude a contract with a restructuring advisor, the Act provides for the determination of the maximum amount of remuneration that can be determined if the debtor is a micro or small entrepreneur. Specifying the maximum amount of remuneration is to protect debtors with less financial potential from concluding contracts with a restructuring advisor that impede its performance.

\section{j) Limitations in managing the debtor's assets.}

The Act also provides for the limitation of the debtor's rights in managing his assets during the proceedings, in line with the regulations provided for in the case of accelerated arrangement proceedings. The debtor - in the period from the date of publication of the opening the proceedings to the end of the proceedings - cannot perform activities beyond ordinary management without the consent of the arrangement supervisor ${ }^{22}$ Creditors, during the course of the proceedings, cannot enforce claims, even those secured on debtor's assets.

\section{k) Securing new financing}

There is no doubt that, apart from the suspension of enforcement liabilities, the key solution for concluding an arrangement with creditors is obtaining new financing by the debtor, which will be protected if the restructuring is not successful. The debtor may obtain a new financing, if he obtains the consent of the arrangement supervisor. At the same time, special criteria were specified which must be followed by the arrangement supervisor in order to consent to the performance of activities enabling the debtor to receive new financing ${ }^{23}$.

21 Print no. 382 of the Sejm (Lower Chamber of the Polish Parliament) of the 9th Term

22 Print no. 382 of the Sejm (Lower Chamber of the Polish Parliament) of the 9th Term

23 Print no. 382 of the Sejm (Lower Chamber of the Polish Parliament) of the 9th Term 
ICLR, 2020, Vol. 20, No. 1.

l) Exclusion of liability for failure to file for bankruptcy.

Regardless of the final result of the proceedings, the debtor acting in good faith will be protected against claims arising from the untimely filing of a bankruptcy petition resulting from bankruptcy law, the Code of Commercial Companies and the Tax Ordinance Act. The condition for excluding liability is the opening of the proceedings referred and the conclusion of an arrangement. In the event that it proves impossible, the Act requires, in order to exclude the liability of the debtor, to make a quick decision ( 7 days) to submit a bankruptcy petition or a petition to open restructuring proceedings. In the latter case, in order to obtain the exclusion of liability, it is necessary to open restructuring proceedings $^{24}$.

\section{m) Liability.}

In order to protect the interests of creditors, the Act provides for the obligation to redress the damage for the debtor who submitted the application for the opening of proceedings in bad faith ${ }^{25}$.

\section{Conclusions}

Simplified restructuring proceedings may be initiated by an entrepreneur in the event of the debtor's insolvency or in the event of a threat of his insolvency. However the fact of insolvency may have not any direct or indirect link to the COVID-19 pandemic. The cause of the insolvency is not legally significant. It should be expected that the simplified procedure will „cannibalize“ other four modes of restructuring proceedings.

The main advantages of this procedure are bankruptcy prevention, simplicity and cheapness of the procedure. An important argument is the speed of its initiation. An entrepreneur making a decision about restructuring may almost immediately open this procedure. A debtor gains anti-enforcement protection.

It can be expected that this regulation will set a new trend in the development of restructuring law.

\section{References}

ADAMUS Rafał, Bankruptcy and Restructuring Law in Poland, Societas et Iurisprudentia 2019, vol. VII, issue 2, Trnava, Slovakia

ADAMUS Rafał, Grounds for opening restructuring proceedings in Poland, Gaps in Russian Legislation, Moscow 2018, no 7

ADAMUS Rafal, The need for change in the approach to insolvency of sports clubs in the regulation of the European football federation, Balkan Social Science Review 2020, vol. 15

24 Print no. 382 of the Sejm (Lower Chamber of the Polish Parliament) of the 9th Term

25 Print no. 382 of the Sejm (Lower Chamber of the Polish Parliament) of the 9th Term 
ADAMUS Rafal, The need for a special restructuring procedure for insolvent entrepreneurs due to SARS-CoV-2, Sociopolitical Sciences, Moscow nr 2/2020

ADAMUS Rafał, Następcza niemożność świadczenia wynajmującego $z$ terminowej umowy najmu, Folia Iuridica Universitatis Wratislaviensis 2019, vol. 8 (2)

ADAMUS Rafał, Partial arrangement in the Polish Reorganization Law, Gaps in Russian Legislation, Moscow 2018, no 6

ALTMAN Edward, HOTCHKISS Edith, WANG Wey, Corporate Financial Distress, Restructuring, and Bankruptcy: Analyze Leveraged Finance, Distressed Debt, and Bankruptcy, Wiley Finance, 4th Edition

BEIRNE John, RENZHI Nuobu, SUGANDI Eric, and VOLZ Ulrich, Financial Market and Capital Flow Dynamics During the COVID-19 Pandemic

GUERRA - MARTINEZ Aurelio, Insolvency Law in Times of COVID-19,

Print no. 382 of the Sejm (Lower Chamber of the Polish Parliament) of the 9th Term.

LEWTIN Adam, Business Bankruptcy: Financial Restructuring and Modern Commercial Markets, Wolters Kluwer 2019

UNICITRAL Legislative Guide on Insolvency. Part One. Designing the Key Objectives and Structure of an Effective and Efficient Insolvency Law, New York 2005 